\section{Assessing Organic Contaminants in Fish: Comparison of a Nonlethal Tissue Sampling Technique to Mobile and Stationary Passive Sampling Devices}

\author{
REBECCA M. HELTSLEY, ${ }^{\dagger}$ \\ W. GREGORY COPE, * DAMIAN SHEA, AND \\ R O B E R T B. B R I N G O L F \\ Department of Environmental and Molecular Toxicology, \\ North Carolina State University, Box 7633, \\ Raleigh, North Carolina 27695-7633 \\ THOMAS J. KWAK AND \\ E D WARD G. MALIN D ZAK \\ U.S. Geological Survey, North Carolina Cooperative Fish and \\ Wildlife Research Unit, Department of Zoology, \\ North Carolina State University, Box 7617, \\ Raleigh, North Carolina 27695-7617
}

As concerns mount over the human health risks associated with consumption of fish contaminated with persistent organic pollutants, there exists a need to better evaluate fish body burdens without lethally sampling many of the important commercial and sport species of interest. The aim of this study was to investigate two novel methods for estimating organic contaminants in fish that are a concern for both fish and human health. The removal of fish adipose fins, commonly done in mark-recapture studies with salmonid species, was evaluated as a nonlethal sampling technique to estimate concentrations of polychlorinated biphenyls (PCBs) and organochlorine pesticides (OCPs) in flathead catfish (Pylodictis olivaris), relative to those found in muscle fillets of the same fish. We also assessed the efficacy of using poly(dimethylsiloxane) (PDMS) as a mobile passive sampling device (PSD) attached directly to wild flathead catfish for assessing location-specific exposure of the fish to waterborne contaminants. The results of this study have demonstrated for the first time that organic contaminant concentrations in adipose fin were highly correlated $\left(R^{2}=0.87\right)$ with muscle fillet concentrations, indicating that the adipose fin of certain fishes may be used to accurately estimate tissue concentrations without the need for lethal sampling. Moreover, mobile PSDs attached directly to fish and used here for the first time accurately estimated ultratrace concentrations of waterborne PCBs and OCPs without any apparent harm to the fish, indicating that there are no practical or physical barriers to the use of mobile passive samplers attached to aquatic organisms. Among the many practical implications of this research, two potential priority items include the analysis of organic contaminants in farm-raised and sport fish intended for human consumption, without the economic and population

\footnotetext{
* Corresponding author phone: (919)515-5296; fax: (919)515-7169; e-mail: greg_cope@ncsu.edu.

${ }^{\dagger}$ Present address: National Institute of Standards and Technology, Hollings Marine Laboratory, Charleston, SC 29412.
}

losses associated with lethally sampling fish to obtain tissues, and identifying specific areas where fish may be accumulating large portions of their contaminant burden.

\section{Introduction}

Nonlethal or noninvasive tissue sampling techniques for monitoring contaminants in fish are an attractive alternative to the traditional lethal methods of obtaining muscle fillets. However, concerns related to nonlethal sampling must also be considered; these include postsampling survival of the organism and whether the typical small sample size and subsequent tissue extraction procedures will yield detectable and comparable results to those obtained from whole fish or muscle fillets. Recently, Baker et al. (1) applied this concept successfully with muscle tissue biopsies from lake whitefish (Coregonus clupeaformis) and northern pike (Esox lucius) for the analysis of mercury $(\mathrm{Hg})$ and found that concentrations were similar to those from whole fish. They also found that, after 1 year postbiopsy, there were no differences in survival between the nonlethally sampled fish and the nonbiopsied controls (1). Other studies have used nonlethal sampling techniques to obtain information on genetic profiles of fish populations by sampling low-risk tissues such as erythrocytes; blood plasma; caudal, pelvic, and adipose fin; and scale-epithelial tissue with little to no adverse effects on individual fish $(2,3)$.

The adipose fin of fish is a small, fleshy, lipid-laden, nonrayed fin that is highly conserved among some basal teleosts (4) such as salmonids (e.g., salmon, trout) and ictalurids (e.g., catfish). The removal of the adipose fin has been used for many decades by fishery scientists in markrecapture studies to estimate population sizes, primarily in species belonging to the family Salmonidae (5). For example, in 1984, over 6 million steelhead (Oncorhynchus mykiss) from a hatchery in Idaho were marked with an adipose fin clip to differentiate between wild and hatchery raised fish. Prior to release, the trout were examined for clip healing and mortality. Complete healing of the excision was observed in less than 4 weeks, and from the 6 million fish marked, only $0.3 \%$ mortality was observed (6). Numerous other studies have reported that adipose fins clipped from various species of catfish, trout, and salmon for marking purposes have not caused deleterious effects on growth, weight, or condition of fish and that the approximate cost of performing an adipose fin clip is as low as 2 cents per fish (US $\$ 0.02)(5,7,8)$.

Despite the remarkably low occurrence of adverse effects to fish from removing the adipose fin, coupled with its relatively low-cost to perform, there have been no reports, to our knowledge, investigating the use of nonlethal sampling of the adipose fin to estimate concentrations of organic contaminants. An extensive search of primary literature databases revealed only one study in which the adipose fin of fish had been evaluated for its indicative value in contaminant assessments; that study involved the assessment of $\mathrm{Hg}$ in brown trout (Salmo trutta) and was conducted in 1986 (9).

Likewise, there are many limitations associated with sampling and measuring ultratrace concentrations of contaminants in surface waters to predict exposure and bioaccumulation of chemicals in fish tissue. The use of passive sampling devices (PSDs) has offered a relatively new and less labor intensive method of monitoring waterborne contaminants for biological exposure assessment. PSDs function by passively accumulating hydrophobic organic contaminants (HOCs) in a polymeric (lipid-like) membrane in a time-integrated manner. The most common use of PSDs is to provide an estimate of exposure concentrations in water. 
This process requires additional kinetic information (uptake rate constants) that can be determined in controlled laboratory or field settings $(10-12)$. Uptake rate constants have been determined for many environmental pollutants that have known toxicological consequences in aquatic organisms, including polycyclic aromatic hydrocarbons (PAHs), polychlorinated biphenyls (PCBs), and organochlorine pesticides (OCPs) for passive samplers, such as semipermeable membrane devices (SPMDs) and chemical exposure dosimeters (CEDs) $(10,11,13-16)$.

Because PSDs passively accumulate contaminants into lipid-like phases, not only do they function as a means to estimate environmental exposure concentrations but they also serve as a biomimetic tool by mimicking the uptake of HOCs by aquatic organisms from the water phase. Many studies have examined the potential of using SPMDs to correlate uptake of HOCs with finfish $(10,17)$. The strength of this correlation has been dependent upon the species examined, because different fish species are unique in their ability to metabolize xenobiotics, contain different body lipid compositions, and vary in food habits and migratory patterns. The best correlations have been observed with persistent, lipophilic compounds that have minimal dietary uptake in organisms (12).

We initiated research to study the potential of using adipose fin tissue as a nonlethal sampling technique to assess fish contamination by PCBs and OCPs and to test the efficacy of externally attaching PSDs directly to individual fish (a mobile PSD) to determine location-specific contaminant concentrations, in conjunction with an ongoing population study of flathead catfish (Pylodictis olivaris) in the Deep River of North Carolina, during the summer of 2004. The concentrations of PCBs and OCPs measured in the adipose fin of fish were compared to those obtained from mobile PSDs (i.e., the PSDs that were affixed directly to the flathead catfish), as well as stationary PSDs deployed at sites in the river. Therefore, the objectives of this study were to determine if adipose fin tissue provides an accurate estimate of organic contaminant concentrations in fish axial muscle fillets and if mobile PSD technology can be used as a tool for measuring location-specific organic contaminants in fish.

\section{Experimental Section}

Site Description. The study area was in an impounded reach of the Deep River in Moore and Lee counties of North Carolina. The area is approximately $25 \mathrm{~km}$ west of Sanford, $\mathrm{NC}$, and $220 \mathrm{~km}$ from the mouth of the Cape Fear River, where it discharges into the Atlantic Ocean. The study reach was located between the Glendon-Carthage Road Bridge and Carbonton Dam and is a medium-sized river in the upper Cape Fear drainage at this location. The stream reach contains relatively slow-flowing water with depths that may exceed $6 \mathrm{~m}$ at base flow. This section of the Deep River has been shown to be relatively uncontaminated by organic pollutants (18) and thus provided a rigorous test of the adipose fin and PSD sampling techniques for detecting and measuring lowlevel contamination.

Materials. Mobile PSDs were attached directly to wild flathead catfish confined to the study reach (a non-native, naturalized population). The mobile PSDs (and a set of three stationary PSDs deployed at a site in the river) were composed of virgin poly(dimethylsiloxane) (PDMS) sheeting $(0.16 \mathrm{~cm}$ thick) manufactured by Diversified Silicone Products Inc. (Santa Fe Springs, CA) and purchased from McMaster Carr (Atlanta, GA). PDMS disks were constructed by punching circles (14 mm diameter) from the PDMS sheet with a cork punch. The average weight of a PDMS disk was $0.3 \mathrm{~g}(n=$ 324 disks made). The PDMS disks were placed in a $20-\mathrm{mL}$ vial containing $18 \mathrm{~mL}$ of acetone and shaker-extracted (350 $\mathrm{rpm}$ ) for $30 \mathrm{~min}$. This pre-extraction process was repeated five times with fresh solvent, and the clean disks were then placed in solvent-rinsed foil and dried in a $60^{\circ} \mathrm{C}$ oven for 10 min. Following pre-extraction, PDMS disks were fortified with two performance reference compounds [PRCs $\mathrm{Cl}(02)$ and $\mathrm{Cl} 2(11)]$ prior to deployment following methods described by Booij et al. (19), with the following two modifications: PRCs were spiked into a 50:50 methanol:water solution and PDMS disks were added to the solution and allowed to shake overnight (minimum of $8 \mathrm{~h}$ ).

For comparative purposes, another set of two stationary PSDs, composed of virgin low-density polyethylene (LDPE) tubing (75 $\mathrm{mm}$ wide and $1 \mathrm{~mm}$ thick) was deployed alongside the PDMS stationary PSDs at a site in the river. Each LDPE sampler, purchased from Brentwood Plastics Inc. (St. Louis, $\mathrm{MO}$ ), was $75 \mathrm{~mm}$ wide and $250 \mathrm{~mm}$ in length. LDPE strips were extracted in hexane overnight prior to use. To avoid contamination of samples, all glassware, aluminum foil, stainless steel wiring, and sodium sulfate were either baked at $300{ }^{\circ} \mathrm{C}$ overnight or rinsed three times each with acetone, methylene chloride, and hexane, as appropriate. All solvents used in this study were Ultra Resi-Analyzed grade purchased from J.T. Baker Inc. (Phillipsburg, NJ). Polychlorinated biphenyls and organochlorine mixtures for use in spike recovery studies and residue analysis were purchased from AccuStandard Inc. (New Haven, CT).

Sample Collection. Between May 12 and June 29, 2004, 108 flathead catfish were collected by standard boatmounted, low-frequency, pulsed-DC, electrofishing methods from the study reach of the Deep River. Once captured, the fish were promptly measured (total length in $\mathrm{mm}$ ) and weighed (wet weight in g), and a medium Floy T-Bar Anchor Tag (7.62 cm long), modified to carry three PDMS disks, was attached to each fish. Each PDMS disk was separated by a $5-\mathrm{mm}$ piece of polyethylene aquarium tubing as a spacer, and the modified anchor tag was inserted into the axial muscle tissue of the fish near the insertion of the dorsal fin (Figure 1). The PDMS disks and spacers were threaded onto the anchor tag by hand using latex gloves immediately prior to tagging to minimize contamination. The free end of the anchor tag was doubled over and held secure with a small polyethylene tie-wrap to prevent the PDMS disks from slipping from the anchor tag while attached to the fish. The unique anchor tag number associated with each fish was recorded and the fish was released back into the Deep River.

The sets of stationary PDMS and LDPE samplers were deployed at a site in the study reach of the Deep River just upstream of Carbonton Dam in polypropylene cages that shaded the PSDs from sunlight and protected them from floating debris. All passive samplers (PDMS and LDPE) were deployed for a minimum 21-d exposure period.

After the minimum 21-d deployment period, four 1-d electrofishing outings were conducted for recovery of tagged flathead catfish. Upon recapturing a PDMS tagged flathead catfish, the tag number was recorded and the fish was measured, weighed, euthanized, and held on ice in the field. The fish (with tags still attached) were then transported to the Analytical Toxicology Laboratory in the Department of Environmental and Molecular Toxicology at North Carolina State University and stored frozen $\left(-20^{\circ} \mathrm{C}\right)$ until processing.

Sample Extraction and Analysis. At the time of processing, PDMS disks were removed from the anchor tags of fish (mobile sampler) or stainless steel wire (stationary sampler) and rinsed with deionized water to remove any biofilm. Each of the PDMS disks were cut into four small pieces with solventrinsed stainless steel scissors; spiked with a surrogate internal standard (SIS) mix containing dibromooctafluorobiphenyl (DBOFB), Cl5(112), and Cl8(197); and serially extracted three times in $4.5-\mathrm{mL}$ vials on a shaker-table with a total $10 \mathrm{~mL}$ of acetone. Total extraction time was approximately $14 \mathrm{~h}$. Extracts were collected and concentrated to less than $4 \mathrm{~mL}$ with a gentle stream of nitrogen and then filtered with a 

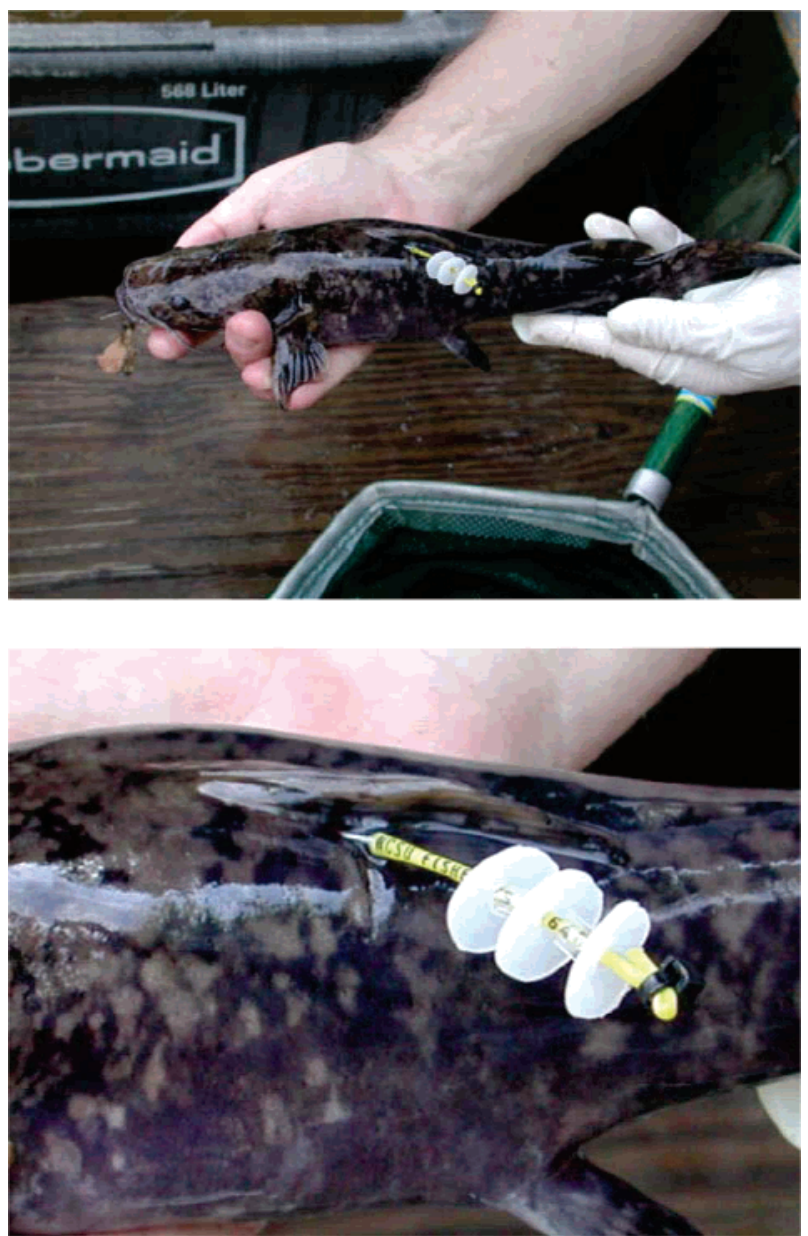

FIGURE 1. Photographs of the poly(dimethylsiloxane) (PDMS) mobile passive sampling device attached to a flathead catfish collected from the Deep River of North Carolina.

Whatman Uniprep filter vial, $0.45 \mu \mathrm{m}$ poly(tetrafluoroethylene) (PTFE). The filtered extract was further concentrated with nitrogen to $0.5 \mathrm{~mL}$ and spiked with a recovery internal standard, tetrachloro- $m$-xylene (TCMX).

LDPE strips were rinsed with deionized water, cut into small pieces with solvent-rinsed stainless steel scissors, spiked with SIS, and serially extracted three times in Teflon bottles on a shaker-table with a total of $150 \mathrm{~mL}$ of methylene chloride. Extracts were combined, filtered with a Whatman Uniprep filter, and concentrated to $1 \mathrm{~mL}$. Any waxes were then removed by gel permeation chromatography (GPC). The final extract was solvent exchanged to hexane and evaporated to $0.5 \mathrm{~mL}$ and spiked with TCMX.

Samples of adipose fin and axial muscle fillet (right dorsal) were dissected from each of the recaptured flathead catfish bearing an anchor tag and extracted in the following manner. The adipose fin was removed with a stainless steel solventrinsed scalpel, weighed, cut into smaller pieces, spiked with SIS, mixed with sodium sulfate, and serially extracted three times in Teflon bottles on a shaker-table with a total of 15 $\mathrm{mL}$ of methylene chloride. The axial muscle fillet was dissected with a stainless steel solvent-rinsed fillet knife, weighed, homogenized, spiked with SIS, mixed with sodium sulfate, and serially extracted in Teflon bottles on a shakertable with methylene chloride (1:40 fresh wet weight to solvent volume ratio). Total extraction times for the fish tissues were $24 \mathrm{~h}$. Solvent from the three sequential muscle extractions was combined and reduced in volume by rotary evaporation at $35^{\circ} \mathrm{C}$ to $35 \mathrm{~mL}$. A gentle stream of nitrogen further reduced the extracts from both the muscle tissue and the adipose fin tissue to less than $4 \mathrm{~mL}$. Extracts were then filtered with $0.45-$ $\mu \mathrm{m}$ PTFE syringeless filters. GPC was used to separate lipids from the pollutant fraction. The fraction containing the target analytes was solvent exchanged to hexane and reduced in volume to $1.5 \mathrm{~mL}$. The concentrated extracts were applied to the top of a hexane-conditioned silica column. PCBs and OCPs were eluted with hexane and methylene chloride, solvent exchanged to hexane, concentrated to $0.5 \mathrm{~mL}$, and spiked with TCMX. Lipid fractions were determined by evaporating and weighing lipid in an aluminum pan.

PCBs and OCPs were analyzed using an Agilent 6890 gas chromatograph (GC) equipped with electronic pressure control connected to a 5973n mass selective detector or an electron capture detector (ECD). For GC-ECD analysis, extracts were injected in the pulsed splitless mode and separated on a $30-\mathrm{m} \times 0.32-\mathrm{mm} \mathrm{ZB}-50(0.25-\mu \mathrm{m}$ film thickness $)$ fused silica capillary (Phenomenex, Inc. Torrance, CA). The temperature was programmed as follows: initial temperature $60{ }^{\circ} \mathrm{C}$ for $1.4 \mathrm{~min}, 20^{\circ} \mathrm{C} / \mathrm{min}$ to $210^{\circ} \mathrm{C}, 1^{\circ} \mathrm{C} / \mathrm{min}$ to $250{ }^{\circ} \mathrm{C}$, $10^{\circ} \mathrm{C} / \mathrm{min}$ to $300^{\circ} \mathrm{C}$, hold for $7 \mathrm{~min}$. The injector and detector were set at $300^{\circ} \mathrm{C}$. For GC-MS analysis, extracts were injected in pulsed splitless mode and separated on a Restek $30-\mathrm{m} \times$ $0.25-\mathrm{mm}$ Rtx-5 $(0.25-\mu \mathrm{m}$ film thickness) MS with IntegraGuard column. The pressure was ramped to 30 psi before injections with a 1-min hold time. The pressure was then dropped to a constant flow of $1 \mathrm{~mL} / \mathrm{min}$ for the duration of the run. The temperature program was as follows: initial temperature $50{ }^{\circ} \mathrm{C}$ for $1.0 \mathrm{~min}, 25^{\circ} \mathrm{C} / \mathrm{min}$ to $100{ }^{\circ} \mathrm{C}, 15^{\circ} \mathrm{C} /$ $\min$ to $245^{\circ} \mathrm{C}, 0.5^{\circ} \mathrm{C} / \mathrm{min}$ to $247^{\circ} \mathrm{C}, 10^{\circ} \mathrm{C} / \mathrm{min}$ to $300{ }^{\circ} \mathrm{C}$, hold for $5 \mathrm{~min}$. The injector and detector were set at $300^{\circ} \mathrm{C}$. Selected ion monitoring (SIM) was used for the analysis.

Response factors were generated using a four- or fivepoint calibration curve, and response was monitored using the midlevel calibration standard. The relative percent difference between the midlevel check was always less than $15 \%$ for all analytes. Sample concentrations were calculated using the generated response factors and were based on the known amount of TCMX injected. A rigorous quality assurance protocol that included the measurement of solvent blanks, procedural blanks, replicate analyses, matrix spikes, and SIS recovery was followed during all analyses. Matrix spike recoveries ranged from 45 to $114 \%$, surrogate recoveries for muscle tissue were all $>70 \%$, surrogate recoveries for adipose fin were all $>50 \%$, laboratory replicate relative standard deviations were $<15 \%$, and method blanks were not detected. The data were not corrected for recovery. Method detection limits were as follows: PDMS ranged from 0.004 to $0.08 \mathrm{ng} / \mathrm{g}$ disk (GC-ECD) and muscle and adipose fin tissue ranged from 0.2 to $0.5 \mathrm{ng} / \mathrm{g}(\mathrm{GC}-\mathrm{MS})$ dry weight. Fish contaminant data were normalized for lipid content and are reported as ng/g lipid weight. The relation among contaminant concentrations in adipose and muscle tissue of fish and PSDs was evaluated with linear regression and Pearson correlation analysis.

\section{Results and Discussion}

Of the 108 flathead catfish tagged with PDMS anchor tags, a total of seven fish were recovered from the Deep River (Table 1), resulting in a $6.5 \%$ recapture rate. This recapture rate was well within the range $(3-10 \%)$ of that expected for riverine flathead catfish populations sampled with our electrofishing method $(20,21)$, which is considered the most effective technique for collecting this species (22-24). These seven fish provided a robust number of samples to assess the relation of contaminant uptake into PDMS passive samplers to that accumulated in fish tissues. The total length of the fish recovered with PDMS anchor tags averaged 304 $\mathrm{mm}$ (range 215-518 $\mathrm{mm}$ ) and weighed from 68 to $1352 \mathrm{~g}$ wet weight (Table 1). The wet weight of adipose fin samples averaged $1.1 \mathrm{~g}$ and contained a mean lipid content of $13 \%$, 
TABLE 1. Tagging and Recapture Dates, Total Length, Wet Weight, Extracted Tissue Wet Weight, and Lipid Content of Flathead Catfish Collected from the Deep River of North Carolina

\begin{tabular}{|c|c|c|c|c|c|c|c|c|c|}
\hline \multirow[b]{2}{*}{$\begin{array}{l}\text { fish tag no./ } \\
\text { sample ID }\end{array}$} & \multicolumn{2}{|c|}{ date in 2004} & \multirow{2}{*}{$\begin{array}{l}\text { PDMS a tag } \\
\text { deployment } \\
\text { (d) }\end{array}$} & \multirow{2}{*}{$\begin{array}{c}\text { total } \\
\text { length } \\
(\mathrm{mm})\end{array}$} & \multicolumn{3}{|c|}{ wet weight (g) } & \multicolumn{2}{|c|}{ lipid content (\%) } \\
\hline & tagged & recaptured & & & $\begin{array}{l}\text { whole } \\
\text { fish }\end{array}$ & fillet & $\begin{array}{l}\text { adipose } \\
\text { fin }\end{array}$ & $\begin{array}{c}\text { muscle } \\
\text { tissue }\end{array}$ & $\begin{array}{c}\text { adipose } \\
\text { fin }\end{array}$ \\
\hline 24627 & May 12 & Jun 9 & 30 & 242 & 120 & 13.6 & 0.3 & 0.03 & 27.5 \\
\hline 24632 & May 12 & Jun 29 & 36 & 265 & 200 & 24.5 & 0.6 & 0.09 & 21.4 \\
\hline 24666 & Jun 3 & Jun 29 & 25 & 341 & 350 & 24.5 & 1.5 & 0.02 & 12.8 \\
\hline 24171 & Jun 29 & Jul 23 & 29 & 293 & 196 & 21.3 & 0.5 & 0.05 & 3.5 \\
\hline 24158 & Jun 29 & Jul 23 & 29 & 260 & 231 & 21.7 & 0.2 & 0.02 & 10.0 \\
\hline 24163 & Jun 29 & Jul 23 & 29 & 518 & 1352 & 24.9 & 4.2 & 0.46 & 9.5 \\
\hline 24167 & Jun 29 & Jul 23 & 29 & 215 & 68 & 10.3 & 0.1 & 0.04 & 9.4 \\
\hline stationary & Jun 11 & Jul 23 & 41 & - & - & - & - & - & - \\
\hline $\begin{array}{l}\text { stationary } \\
\text { LDPE }^{\text {b }}\end{array}$ & Jun 11 & Jul 23 & 41 & - & - & - & - & - & - \\
\hline
\end{tabular}

TABLE 2. Estimated Sum Water Concentrations of Polychlorinated Biphenyls (PCBs) and Organochlorine Pesticides (OCPs) from Passive Sampling Devices (PSDs) and Corresponding PCB and OCP Concentrations (lipid normalized) Measured in Adipose Fin and Muscle fissue of Flathead Catfish Collected from the Deep River of North Carolina

\begin{tabular}{|c|c|c|c|c|c|c|c|c|c|c|}
\hline & \multirow[b]{2}{*}{ medium } & \multicolumn{7}{|c|}{ PCB and OCP concentrations in individual fish samples } & \multirow{2}{*}{$\begin{array}{c}\text { stationary } \\
\text { PDMS }^{a} \\
\text { PSD }\end{array}$} & \multirow{2}{*}{$\begin{array}{c}\text { stationary } \\
\text { LDPE }^{b} \\
\text { PSD }^{2}\end{array}$} \\
\hline & & 24171 & 24666 & 24158 & 24163 & 24632 & 24167 & 24627 & & \\
\hline \multirow[t]{3}{*}{ PCBs } & PSDs (ng/L) & 7.1 & 13.1 & 4.1 & 2.3 & 0.6 & 1.1 & 1.9 & 2.2 & 3.7 \\
\hline & adipose fin (ng/g) & 150.8 & 230.4 & 2930.4 & 381.1 & 332.5 & 2537.5 & 680.1 & - & - \\
\hline & muscle (ng/g) & 929.1 & 768.2 & 3875.1 & 338.8 & 382.9 & 2069.0 & 777.1 & - & - \\
\hline \multirow{3}{*}{ OCPs } & PSDs (ng/L) & 29.0 & 30.7 & 59.6 & 5.4 & 1.8 & 14.8 & 14.5 & 1.5 & 7.3 \\
\hline & adipose fin (ng/g) & 587.8 & 430.3 & 1150.9 & 291.0 & 207.1 & 795.5 & 245.6 & - & - \\
\hline & muscle (ng/g) & 473.6 & 487.2 & 1270.7 & 240.7 & 237.2 & 665.4 & 373.8 & - & - \\
\hline
\end{tabular}

whereas axial muscle samples had a mean wet weight of 20 $\mathrm{g}$ and a mean lipid content of $0.1 \%$ (Table 1 ).

PCB and OCP Concentrations in Adipose Fin and Muscle Tissue. Although the flathead catfish collected in this study were all relatively small and young (average-size fish was approximately 2 years of age and largest fish was about age 4 or $5 ; 21$ ) and came from a relatively unpolluted system, they had accumulated measurable quantities of PCBs and OCPs in their tissues (Table 2). Moreover, there was a strong linear relation $\left(R^{2}=0.87\right)$ between PCB and OCP concentrations in adipose fin and muscle tissue (Figure 2), illustrating the great potential for analysis of the adipose fin to serve as a nonlethal sampling technique to predict organic contaminant concentrations in muscle tissue. Because flathead catfish often attain a large size (e.g., 9-30 kg), are obligate carnivores and an apex predator in most systems, and are gaining value as a prized sport fish for human consumption, this predictive relation may have implications as a method for monitoring organic contaminants for assessment of human health risk from fish consumption.

The adipose fin is located medially between the dorsal and caudal fins of fish and is somewhat restricted taxonomically; occurring only among eight groups of teleosts (25). However, many of the species in these groups have extensive commercial (economic), recreational (sport fish), and ecological importance, such as those belonging to the families Ictaluridae (catfishes) and Salmonidae (trouts and salmons). Other families of fish like the Osmeridae (smelts) and Percopsidae (trout-perches) also contain species that have adipose fins and may broaden the applicability of using adipose fin clips for monitoring organic contaminants. State and federal fish and wildlife management agency biologists commonly remove the adipose fin of fish for tagging purposes (5), often to identify hatchery-reared trout and salmon from wild fish for population assessments. Because this fin performs no known vital physiological function in fish (26) and is easily accessible and removed in the field, the potential for it to serve as a nonlethal technique to sample biological tissue is great. However, we found that to facilitate comparison of adipose fin and muscle tissue, normalization of contaminant concentrations to lipid content was required due to the greater lipid composition in the adipose fin verses the muscle tissue (Table 1). Once this normalization to lipid was performed, our data showed that concentrations of PCBs and OCPs measured in adipose fins provided an accurate estimate of concentrations commonly obtained by traditional lethal methods of sampling muscle fillets.

The PCB congener profiles of the seven recaptured fish, expressed as logarithmic concentrations, were consistent between the muscle tissue (Figure 3a) and adipose fin (Figure $3 \mathrm{~b})$. The biotransformation of the lower chlorinated PCB congeners in fish has been documented $(27-30)$, which may explain the lack of detection of the di-CB congeners in both tissues. Congeners with five or more chlorines were the most abundantly detected, peaking at hexa-CBs and then decreasing as chlorine number increased further (Figure 4 ). This trend is similar to that previously observed in the marine fishes striped mullet (Mugil cephalus) and spotted seatrout (Cynoscion nebulosus) and supports the hypothesis that heavily chlorinated PCBs may have restricted membrane permeability, which serves to decrease their uptake in fish $(31,32)$. Interestingly, PCB congener 195 was detected in all adipose fin samples in our analyses, whereas only one of the muscle tissue samples had detectable concentrations of Cl8(195).

Advances in analytical chemistry over the past decade have been critical to the development and use of nonlethal sampling techniques. Analytical technology improvements have paved the way for scientists to examine the concentration of contaminants in smaller tissue samples with the accuracy that compares to traditional methods (1). The average 


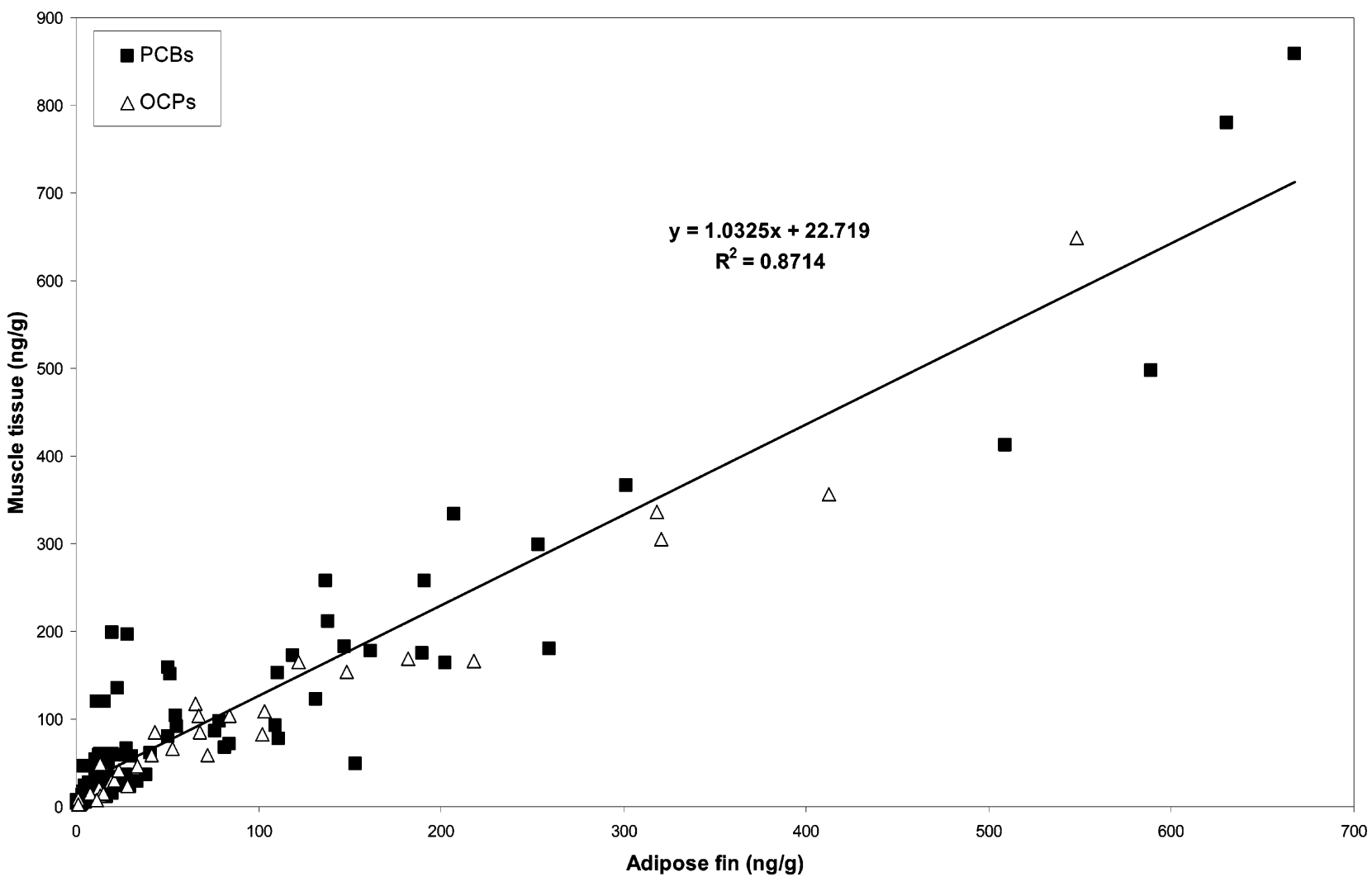

FIGURE 2. Lipid-normalized concentrations of polychlorinated biphenyls (PCBs) and organochlorine pesticides (OCPs) in muscle tissue (fillet) versus adipose fin from individual flathead catfish collected from the Deep River of North Carolina.

ratio of muscle tissue wet weight extracted to adipose fin wet weight extracted was 50:1. Even the smallest adipose fin (0.13 g) analyzed in our study provided an adequate amount of tissue for determination of organic contaminants. This illustrates that accurate measurements of organic contaminants can be determined from small tissue samples that do not require invasive or lethal procedures. Moreover, the analytical advances coupled with smaller tissue sample sizes that are required has the added benefit of reduced solvent use, thereby decreasing the cost of extraction and solvent disposal.

Estimated Exposure Concentrations from Passive Sampling Devices. To our knowledge, this study has demonstrated for the first time the use of mobile PSD technology (i.e., PDMS anchor-tagged fish) for assessing real-time, location-specific exposure of an organism to waterborne contaminants. Using PDMS as a time-integrated passive sampling device is a relatively new technique; however, we found that this technology could detect and measure the presence of PCBs and OCPs (Table 2) in a relatively uncontaminated ecosystem over a 25-36-d deployment period. Another major benefit of this approach is that the PDMS disks attached to the fish with anchor tags showed no signs of harming the fish (e.g., lack of skin abrasion or inflammation) upon recapture beyond the minimal impact of normal anchor-tagging techniques.

The estimated water concentrations of individual PCB congeners and OCPs from the PSDs [estimates obtained by using a standard sampling (uptake) rate equation and empirically derived PRC adjusted sampling rates (33)] were extremely low $(0.2-2 \mathrm{ng} / \mathrm{L})$; therefore, we report the sum of the 21 PCB congeners and the 28 OCPs quantified (Table 2). The primary OCPs detected were similar among samples analyzed and included cis-chlordane, trans-chlordane, 2,4'DDD, 4,4'-DDD, 4,4'-DDE, 2,4'-DDT, dieldrin, heptachlor epoxide, hexachlorobenzene, lindane, mirex, and transnonachlor. The estimated sum concentrations of PCBs in water derived from PDMS anchor-tagged fish (mobile PSDs) ranged from 0.6 to $13.1 \mathrm{ng} / \mathrm{L}$, and the sum concentrations of OCPs ranged from 1.8 to $59.6 \mathrm{ng} / \mathrm{L}$. The exposure concentrations estimated from both the mobile and stationary PSDs were similar to concentrations reported from a previous study that used stationary LDPE PSDs to measure organic pollutants in this same river and general study area (18).

The target analytes in this study were environmentally persistent and extremely lipophilic; log octanol-water partition coefficients $\left(K_{\mathrm{OW}}\right)$ ranged from 3.6 to $8.2(34)$. Therefore, if the role of dietary uptake in the catfish had minimal effects, there should have been a correlation between tissue concentrations estimated from PSDs and measured tissue concentrations; this was not the case in our study. Ellis et al. (17) also observed a poor relation between concentrations of OCPs in SPMDs and carp (Cyprinus carpio), sauger (Sander canadensis), and channel catfish (Ictalurus punctatus) from the Mississippi River. In contrast, Meadows et al. (10), who compared the uptake of PCBs between SPMDs and brown trout, found that uptake rates of the two matrixes were similar within a factor of 2 . Nonetheless, any potential variation between residues accumulated in PSDs and biota could simply be attributed to the role of dietary uptake or metabolism of targeted compounds in fish that are not accounted for in PSDs. Tissue steady-state bioconcentration models are often used to estimate the tissue PCB concentrations using a steady-state bioconcentration factor (BCF) for fish. However, this model does not account for consumption of contaminated food or clearance of chemicals (35). Specific flathead catfish BCF and depuration rate constant values were not available in the published literature; therefore, we used values from Fox et al. (36) for zebrafish (Brachydanio rerio) to predict tissue concentrations from the water concentrations estimated from PSD residues.

Because such low concentrations of the target analytes were detected with the PSDs compared to those detected in the tissues (Table 2), it was unlikely that the water phase was the only source of contaminant uptake for the fish. This relation is further illustrated in Figure 4, which represents 


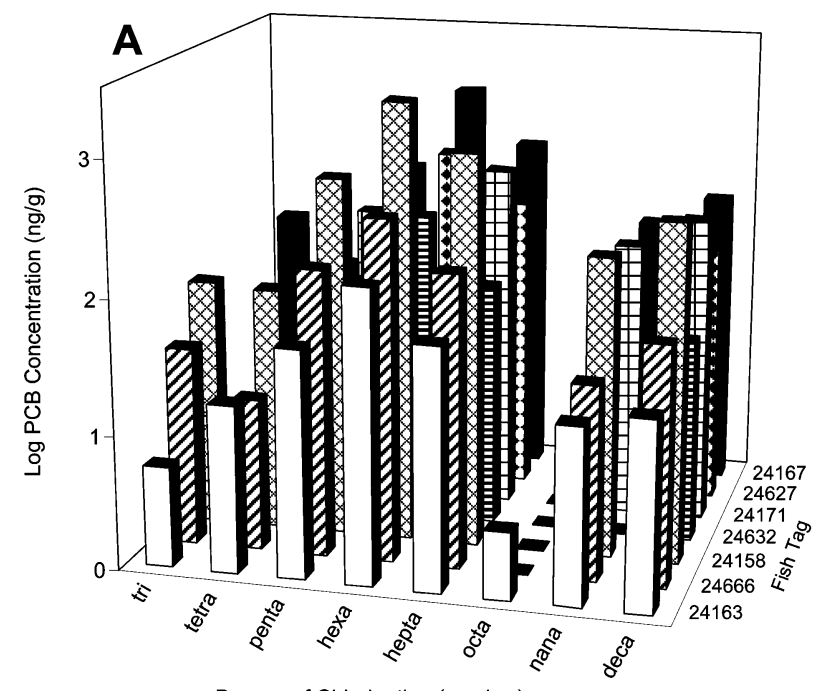

Degree of Chlorination (number)

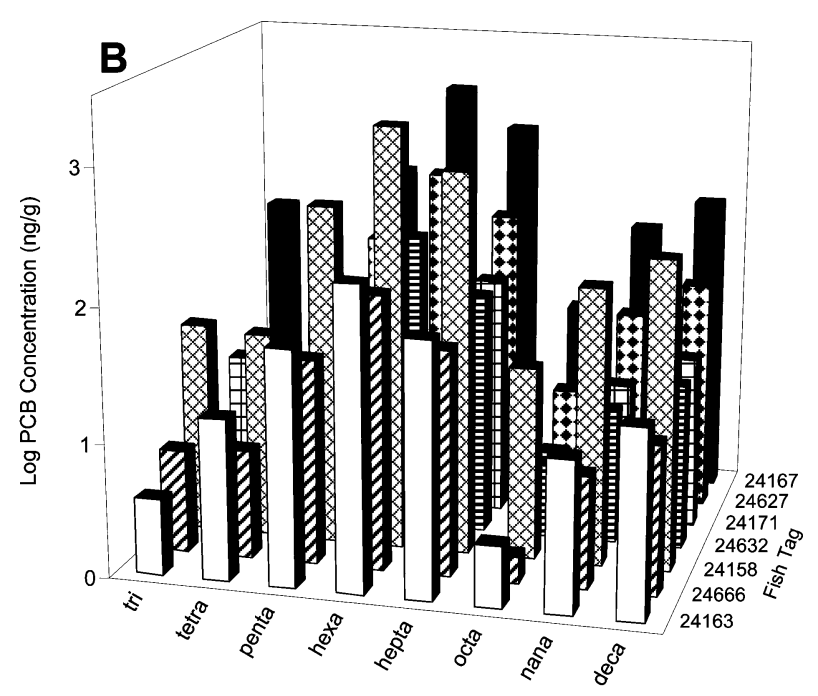

Degree of Chlorination (number)

FIGURE 3. Lipid-normalized concentrations of polychlorinated biphenyl (PCB) congeners in muscle tissue (A) and adipose fin (B) from seven individual flathead catfish (shown from back to front in order of increasing wet weight) collected from the Deep River of North Carolina.

estimated and measured tissue concentrations from the three matrixes examined in this study for fish sample no. 24163. As stated previously, PSDs are most commonly used as a tool to estimate freely dissolved water concentrations. Our PSDs estimated that concentrations of PCBs in the water phase were extremely low, if present at all (Table 2). This corresponded to the low concentrations predicted for tissue concentrations from PSDs, as shown in Figure 4. This pattern is consistent with the fact that PCBs have extremely low water solubilities and tend to partition to sediments, dissolved organic carbon (DOC), or particulate organic carbon (POC) (35). Therefore, PCBs may not be readily available to be sampled by PSDs. On the basis of PCB characteristics in water, and the similarities of water concentrations estimated from PSDs in this study to those measured in a previous study from the same river and general location (18), we were confident in the PSD estimates of PCB concentrations. Interestingly, each of the PSDs deployed in this study detected $\mathrm{Cl}$ (08), which was detected in only one of the muscle tissue samples. The absence of $\mathrm{Cl} 2(08)$ in the majority of tissue sampled could potentially be due to the ability of fish to metabolize lower-chlorinated PCBs (32). Although water concentrations of PCBs estimated from PSDs were low, they were present and detected by our methods. The detection of low concentrations of PCBs can be attributed to the premise behind passive sampling techniques, which allow PSDs to preconcentrate hydrophobic residues over time to concentrations greater than those achieved by traditional sampling techniques such as static, grab water samples that may not have detected PCBs.

Bioaccumulation models may be better suited for estimating HOCs in flathead catfish, because they are susceptible to accumulating PCBs and OCPs from both contaminated sediment and ingestion of contaminated food; they are both predatory and bottom-dwelling fish. Most PCBs have a log $K_{\text {OW }}$ greater than 5; therefore, it is highly likely that bioaccumulation is occurring through trophic transfer in food, which has been confirmed by field studies (37-39), or from DOC, POC, or sediment-associated congeners. This could have resulted in the increased PCB concentrations that were observed in both flathead catfish adipose fin and muscle tissue compared to the predicted tissue concentrations based on water concentrations estimated from PSD residues (Figure 4).

Contribution of PRCs to Predicting Uptake by PSDs. We added PRCs to the PDMS matrix prior to deployment to evaluate how environmental conditions affected the uptake of chlorinated contaminants. Uptake rates of PSDs are known to be affected by environmental conditions, such as water temperature and flow and biofouling of the membrane (12, 40), which are unique to each sampling location and exposure scenario. PRCs are noninterfering (analytically) compounds with water solubilities ( $K_{\mathrm{OW}}$ ) similar to the target compounds of interest, which are added to the PSD prior to deployment. Elimination rates of PRCs from PSDs, determined in laboratory calibration experiments, are proportional to the uptake of target compounds and, consequently, the rate of PRC loss can be used to adjust sampling rates accordingly (12). An equation developed by Huckins et al. (12) was used to determine site-specific elimination rates of PRCs in this study; the equation is used when PRC concentrations are measured prior to deployment and at the end of an exposure study. With that equation, a site-specific PRC elimination rate can be used to calculate an exposure adjustment factor (EAF), which is then used to determine the site-specific sampling rate. The application of PRCs to adjust sampling rates not only reduces the amount of controlled laboratory studies needed to use PSDs but also improves the overall error associated with estimating water concentrations from PSDs (12).

The PRC addition technique proved to be especially useful in this study with mobile PSDs, because increased shear flow across the membrane has been shown to significantly increase the uptake of hydrophobic contaminants with log $K_{\mathrm{OW}}>4.4$ into the PSD (40). In general, the change in initial concentrations of the PRCs should be between 20 and $80 \%$. However, if no loss is observed, then it is assumed that all compounds with $\log K_{\mathrm{OW}}$ greater than that of the PRC are in the linear uptake phase. Conversely, if all of the PRC is lost during a deployment, compounds with $\log K_{\mathrm{OW}}$ similar to that of the PRC will be at equilibrium (12). The PRC loss from the mobile PSDs deployed in this study ranged from 77 to $99 \%$ for $\mathrm{PRC} \mathrm{Cl}(02)$, indicating that all compounds with $\log$ $K_{\text {Ow }}<4.6$ were at equilibrium. Therefore, an equilibrium model should be used for those target analytes, when applicable. Of the 50-plus compounds analyzed in this study, only five had $\log K_{\mathrm{OW}}$ values less than 4.6. Of those five, lindane and $\alpha$-BHC were the only two compounds detected in the PDMS in which water concentrations were estimated with PDMS equilibrium water partition coefficients (33). In this instance, the PDMS no longer provided a time-weightedaverage concentration of lindane and $\alpha$-BHC. The loss of PRC Cl2(11) ranged from 2 to $65 \%$, and the $\log K_{\mathrm{OW}}$ of $\mathrm{Cl} 2(11)$ is 5.3. This loss rate indicates that most of the analytes of 


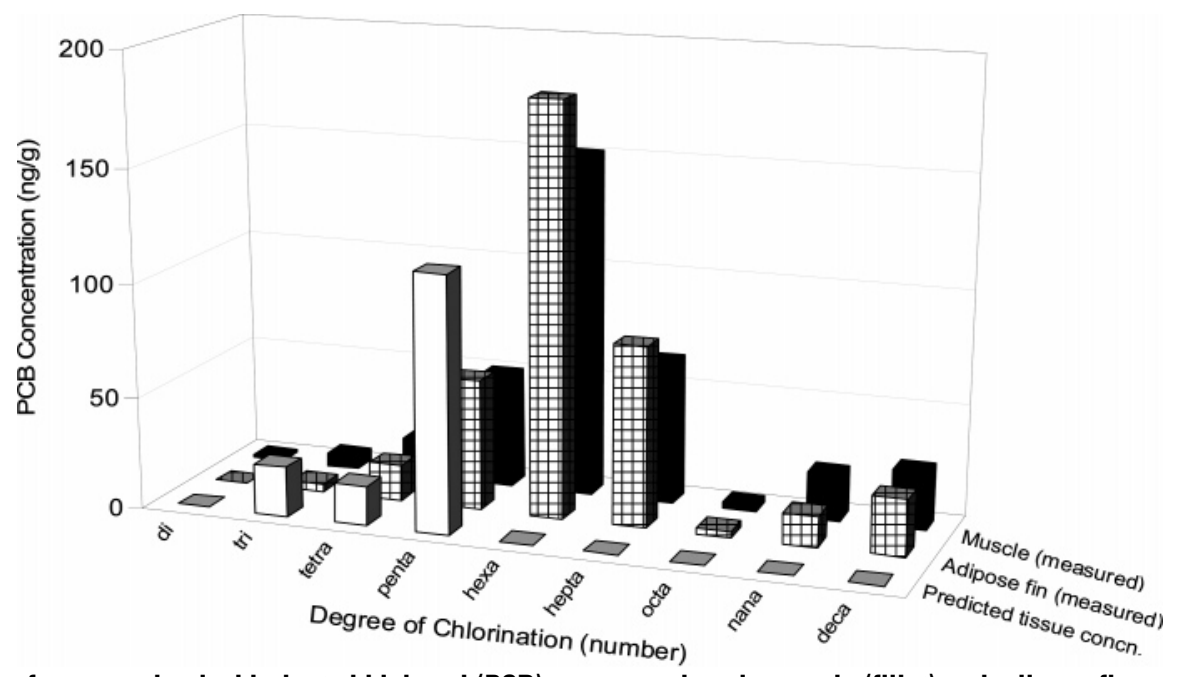

FIGURE 4. Example of measured polychlorinated biphenyl (PCB) concentrations in muscle (fillet) and adipose fin compared to predicted tissue residue based on poly(dimethylsiloxane) (PDMS) disks attached to flathead catfish no. 24163.

interest in this study were in the linear uptake phase, where integrative sampling occurs. The standard sampling (uptake) rate equation with the substitution of the sampling rate that has been adjusted with an EAF (12) was used to estimate the water concentration for all compounds with a $\log K_{\mathrm{OW}}>5.3$.

The stationary PDMS disks deployed in this study had less than $20 \%$ loss for both of the PRCs analyzed. Therefore, a linear uptake model was used to estimate water concentrations from the stationary PDMS disks. These results demonstrate the importance of knowing which model to use when estimating water concentrations from PSDs. Selection of the appropriate phase is dependent on the physicochemical properties of target analytes, exposure duration, and exposure conditions (temperature, biofouling, hydrodynamics).

In summary, the flathead catfish analyzed in this study yielded promising results for using adipose fin removal as a nonlethal sampling technique to assess exposure to, and bioaccumulation of, HOCs. The utility of the adipose fin clip as a nonlethal, noninvasive sampling technique can be judged against criteria developed by Morizot et al. (41), which state that the procedures must indeed be nonlethal and that the techniques employed do not result in adverse effects to the fish. Even though these two outcomes were not specifically examined in this study, the adipose fin removal procedure has been extensively used in mark-recapture studies for many years in fisheries science with little to no adverse effects on the subjected fish $(5,42-44)$. Another decisive factor facilitating the use of nonlethal sampling techniques is the amount of tissue extracted or removed from the fish-there should be ample tissue for the desired analysis. In our study, even the smallest adipose fin sample yielded sensitive analytical results that were highly correlated with PCB and OCP concentrations from the corresponding muscle tissue fillet. The final measure of any successful nonlethal sampling technique is its application to the taxa being studied. This procedure is obviously limited to species of fish that have an adipose fin, which include the Ictaluridae, Salmonidae, Osmeridae, and Percopsidae families of fish, among several others. Although limited, these families of fish include many of the important commercial and sport fish species, such as catfish, salmon, and trout, that are consumed by humans. The ability to assess the contaminant burden in these farmraised and wild fish before human consumption is extremely important $(45,46)$, and obtaining that information without suffering any economic or ecological losses to production or wild populations by nonlethal sampling of the adipose fin would be a tremendous advance. Further, these fish families represent a variety of species with varying habitat use, migratory behavior, feeding modes, and reproductive ecology for application to future research. This approach has wideranging implications and may be especially useful in studies evaluating the effects of organic contaminant exposure for restoration of certain declining fish populations. This would be especially useful to those concerned with threatened or endangered species, in which lethal sampling is not feasible or permitted. Overall, the analysis of adipose fin proved to be a very practical tool that can be used to estimate muscle tissue concentrations of HOCs without harming the fish.

Results from this study also demonstrated for the first time that mobile PSDs made from PDMS disks and attached to fish with anchor tags can be a valuable tool for assessing real-time, location-specific exposure of fish to organic contaminants. The mobile PSD concept, combined with radiotelemetry studies, would offer the ability to measure organic contaminant exposure while at the same time tracking the animal to attempt to determine the ultimate source of contamination (e.g., spawning grounds versus maturation grounds for migratory fish species). In view of this work, there appear to be no practical or physical barriers to the use of mobile PSDs on fish or other aquatic organisms. The PDMS disks fortified with PRCs reflected diverse exposure conditions for mobile PDMS verses the stationary PDMS and allowed us to better estimate site-specific water concentrations of contaminants. Additional research is needed with both of these techniques to confirm our observed relation between contaminant concentrations in adipose fin and muscle tissue for flathead catfish and other applicable species as a nonlethal sampling technique and to further test and evaluate the mobile PSD concept with PDMS for measuring environmental pollutants.

\section{Acknowledgments}

We thank Eun-ah Cho, Michael Fisk, Michael Holliman, Peter Lazaro, William Smith, and Katrina White for assistance in the field and laboratory. The North Carolina Cooperative Fish and Wildlife Research Unit is jointly supported by North Carolina State University, the North Carolina Wildlife Resources Commission, U.S. Geological Survey, and Wildlife Management Institute.

\section{Literature Cited}

(1) Baker, R. F.; Blanchfield, P. J.; Patterson, M. J.; Flett, R. J.; Wesson, L. Evaluation of nonlethal methods for the analysis of mercury in fish tissue. Trans. Am. Fish. Soc. 2004, 133, 568-576.

(2) Carmichael, G. J.; Williamson, M. E.; Schmidt, M. E.; Morizot, D. C. Genetic marker identification in largemouth bass with electrophoresis of low-risk tissues. Trans. Am. Fish. Soc. 1986, $115,455-459$.

VOL. 39, NO. 19, 2005 / ENVIRONMENTAL SCIENCE \& TECHNOLOGY • 7607 
(3) Zhang, Q.; Tiersch, T. R.; Cooper, R. C. Rapid isolation of DNA for genetic screening of catfish by polymerase chain reaction. Trans. Am. Fish. Soc. 1994, 123, 997-1001.

(4) Reimchen, T. E.; Temple, N. F. Hydrodynamic and phylogenetic aspects of the adipose fin in fishes. Can. J. Zool. 2004, 82, 910916.

(5) Hammer, S. A.; Blankenship, H. L. Cost comparison of marks, tags, and mark-with-tag combinations used in salmonid research. North Am. J. Aquacult. 2001, 63, 171-178.

(6) Duke, R. Protection of wild adult steelhead in Idaho by adipose fin removal: Annual report. U.S. Department of Energy, DOE/ $\mathrm{BP} / 14903-1,1987$.

(7) Bryson, W. T.; Lackay, R.; Cairns, J.; Dickson, K. L. Restocking after fishkills as a fisheries management strategy. Trans. Am. Fish. Soc. 1975, 104, 256-263.

(8) Barnes, M. Effects of coded wire tags on feed conversion in rainbow trout. Prog. Fish-Cult. 1994, 56, 291-292.

(9) Skurdal, J.; Skogheim, O. K.; Qvenild, T. Indicative value of mercury concentration in adipose fin of brown trout, Salmo trutta L. J. Fish Biol. 1986, 29, 515-517.

(10) Meadows, J. C.; Echols, K. R.; Huckins, J. N.; Borsuk, F. A.; Carline, R. F.; Tillitt, D. E. Estimation of uptake rate constants for PCB congeners accumulated by semipermeable membrane devices and brown trout (Salmo trutta). Environ. Sci. Technol. 1998, 32, 1847-1852.

(11) Luellen, D. A.; Shea, D. Calibration and field verification of semipermeable membrane devices for measuring polycyclic aromatic hydrocarbons in water. Environ. Sci. Technol. 2002, $36,1791-1797$.

(12) Huckins, J. N.; Petty, J. D.; Prest, H. F.; Clark, R. C.; Alverez, D. A.; Orazio, C. E.; Lebo, J. A.; Cranor, W. L.; Johnson, B. T. A Guide for the Use of Semipermeable Membrane Devices (SPMDs) as Samplers of Waterborne Hydrophobic Organic Contaminants: Report for the American Petroleum Institute (API); API Publication no. 4690, API: Washington, DC, 2002.

(13) Gale, R. W. Three compartment model for contaminant accumulation by semipermeable membrane devices. Environ. Sci. Technol. 1998, 32, 2292-2300.

(14) Huckins, J. N.; Petty, J. D.; Orazio, C. E.; Lebo, J. A.; Clark, R. C.; Gibson, V. L.; Gala, W. R.; Echols, K. R. Determination of uptake kinetics (sampling rates) by lipid-containing semipermeable membrane devices (SPMDs) for polycyclic aromatic hydrocarbons (PAHs) in water. Environ. Sci. Technol. 1999, 33, 3918-3923.

(15) White, K. E.; Shea, D. Uptake of PAHs into poly(dimethylsiloxane) disks from water: An alternative passive sampling device. Abstract, $24^{\text {th }}$ Annual Meeting of the Society of Environmental Toxicology and Chemistry, Austin, TX, 2003.

(16) Heltsley, R. M.; White, K. E.; Shea, D. Measuring bioavailability and chronic exposure of POPs with passive sampling devices. Abstract $25^{\text {th }}$ Annual Meeting of the Society of Environmental Toxicology and Chemistry, Portland, OR, 2004.

(17) Ellis, G. S.; Huckins, J. N.; Rostad, C. E.; Schmitt, C. J.; Petty J. D.; MacCarthy, P. Evaluation of lipid-containing semipermeable membrane devices (SPMDs) for monitoring organochlorine contaminants in the Upper Mississippi River. Environ. Toxicol. Chem. 1995, 14, 1875-1884.

(18) Howard, A. K. Influence of instream physical habitat and water quality on the survival and occurrence of the endangered Cape Fear shiner. M.S. Thesis. North Carolina State University, Raleigh, NC, 2003.

(19) Booij, K.; Smedes, F.; van Weerlee, E. M. Spiking of performance reference compounds in low-density polyethylene and silicone passive water samplers. Chemosphere 2002, 46, 1157-1161.

(20) Pine, W. E., III. Population ecology of introduced flathead catfish. Ph.D. Dissertation, North Carolina State University, Raleigh, NC, 2003.

(21) Kwak, T. J.; Pine, W. E., III; Waters, D. S.; Rice, J. A.; Hightower, J. E.; Noble, R. L. Population dynamics and ecology of introduced flathead catfish: Phase 1 final report. Federal Aid in Sport Fish Restoration Project F-68, Study Number 1, Final Report, Submitted to Division of Inland Fisheries, North Carolina Wildlife Resources Commission, Raleigh, NC, 2004.

(22) Quinn, S. P. Effectiveness of an electrofishing system for collecting flathead catfish. In Developments in electric fishing; Cox, I. G., Ed.; Fishing News Books: Oxford, UK, 1990; pp 123-129.

(23) Justus, B. Observations on electrofishing techniques for three catfish species in Mississippi. Proc. Ann. Conf. Southeastern Assoc. Game Fish Comm. 1994, 48, 524-532.

(24) Stauffer, K. W.; Koenen, B. D. Comparison of methods for sampling flathead catfish in the Minnesota River. In Catfish 2000: Proceedings of the international ictalurid symposium; Irwin, E. R., Hubert, W. A., Rabeni, C. F., Schramm, H. L., Jr.,
Coon, T., Eds. American Fisheries Society, Symposium 24, Bethesda, MD, 1999; pp 329-339.

(25) Nelson, J. S. Fishes of the World; John Wiley \& Sons: New York, 1994.

(26) Helfman, G. S.; Collette, B. B.; Facey, D. E. The Diversity of Fishes Blackwell: Cambridge, MA, 1997.

(27) Sijm, D. T.H. M.; Seinen, W.; Opperhuizen, A. Life-cycle biomagnification study in fish. Environ. Sci. Technol. 1992, 26, 21622174

(28) Brown, J. F., Jr., Metabolic alterations of PCB residues in aquatic fauna: Distributions of cytochrome P4501A- and P4502B-like activities. Mar. Environ. Res. 1992, 34, 261-266.

(29) De Boer, J.; Stronck, C. J. N.; Traag, W.A.; Van der Meer, J. Nonortho and mono-ortho substituted chlorobiphenyls and chlorinated dibenzo- $p$-dioxins and dibenzofurans in marine and freshwater fish and shellfish from The Netherlands. Chemosphere 1993, 26, 1823-1842.

(30) Elskus, A. A.; Stegeman, J. J.; Gooch, J. W.; Black, D. E.; Pruell, R. J. Polychlorinated biphenyl congener distributions in winter flounder as related to gender, spawning site, and congener metabolism. Environ. Sci. Technol. 1994, 28, 401-407.

(31) Maruya, K. A.; Lee, R. F. Biota-sediment accumulation and trophic transfer factors for extremely hydrophobic polychlorinated biphenyls. Environ. Toxicol. Chem. 1998, 17, 2463-2469.

(32) Kannan, K.; Nakata, H.; Stafford, R.; Masson, G. R.; Tanabe, S. Giesy, J. P. Bioaccumulation and toxic potential of extremely hydrophobic polychlorinated biphenyl congeners in biota collected at a superfund site contaminated with Aroclor 1268. Environ. Sci. Technol. 1998, 32, 1214-1221.

(33) Heltsley, R. M. Novel methods for monitoring chlorinated contaminants in aquatic environments. Ph.D. Dissertation, North Carolina State University, Raleigh, NC, 2004.

(34) Mackay, D.; Shiu, W. Y.; Ma, K. C. Illustrated Handbook of Physical-Chemical Properties and Environmental Fate for Organic Chemicals; Lewis: Boca Raton, FL, 1992.

(35) Echols, K. R.; Gale, R. W.; Schwartz, T. R.; Huckins, J. N.; Williams, L. L.; Meadows, J. C.; Morse, D.; Petty, J. D.; Orazio, C. E.; Tillitt, D. E. Comparing polychlorinated biphenyl concentrations and patterns in the Saginaw River using sediment, caged fish, and semipermeable membrane devices. Environ. Sci. Technol. 2000, 34, 4095-4102.

(36) Fox, K.; Zauke, G.; Butte, W. Kinetics of bioconcentration and clearance of 28 polychlorinated biphenyl congeners in zebrafish (Brachydanio rerio). Ecotoxicol. Environ. Safety 1994, 28, 99-109.

(37) Van der Oost, R.; Heida, H.; Opperhuizen, A. Polychlorinated biphenyl congeners in sediments, plankton, molluscs, crustaceans, and eel in a freshwater lake: Implications of using reference chemicals and indicator organisms in bioaccumulation studies. Arch. Environ. Contam. Toxicol. 1988, 17, 721-729.

(38) Zaranko, D. T.; Griffiths, R. W.; Kaushik, N. K. Biomagnification of polychlorinated biphenyls through a riverine food web. Environ. Toxicol. Chem. 1997, 16, 1463-1471.

(39) Metcalfe, T. L.; Metcalfe, C. D. The trophodynamics of PCBs, including mono- and non-ortho congeners, in the food web of North-Central Lake Ontario. Sci. TotalEnviron. 1997, 201,245-272.

(40) Booij, K.; Sleiderink, H. M.; Smedes, F. Calibrating the uptake kinetics of semipermeable membrane devices using exposure standards. Environ. Toxicol. Chem. 1998, 17, 1236-1245.

(41) Morizot, D. C.; Schmidt, M. E.; Carmichael, G. J.; Stock, D. W. Williamson, J. H. Minimally invasive tissue sampling. In Electrophoretic and Isoelectric Focusing Techniques in Fisheries Management; Whitmore, D. H., Ed.; CRC: Boca Raton, FL, 1990; pp 143-156.

(42) Vincent-Lang, D. Relative survival of unmarked and fin-clipped coho salmon from Bear Lake, Alaska. Prog. Fish-Cult. 1993, 55, $141-148$.

(43) Zerrenner, A.; Josephson, D. C.; Krueger, C. C. Growth, mortality, and mark retention of hatchery brook trout marked with visible implant tags, jaw tags, and adipose fin clips. Prog. Fish-Cult. 1997, 59, 241-245.

(44) Gjerde, B.; Refstie, T. The effect of fin-clipping on growth rate, survival and sexual maturity of rainbow trout. Aquaculture 1998, 73, 383-389.

(45) Hites, R. A.; Foran, J. A.; Carpenter, D. O.; Hamilton, M. C.; Knuth, B. A.; Schwager, S. J. Global assessment of organic contaminants in farmed salmon. Science 2004, 303, 226-229.

(46) Hites, R. A.; Foran, J. A.; Schwager, S. J.; Knuth, B. A.; Hamilton, M. C.; Carpenter, D. O. Global assessment of polybrominated diphenyl ethers in farmed and wild salmon. Environ. Sci. Technol. 2004, 38, 4945-4949.

Received for review June 2, 2005. Revised manuscript received July 20, 2005. Accepted July 26, 2005.

ES051037S 